\title{
Optimisation of the use of biomass for energy production (Optimierung der energetischen Biomassenutzung)-a funding programme introduces itself
}

\author{
Daniela Thrän ${ }^{1 *}$, Diana Pfeiffer ${ }^{2}$, Angela Gröber ${ }^{2}$, Stefan Steiert ${ }^{3}$, Vanessa Zeller ${ }^{2}$, Christian Weiser ${ }^{4}$, \\ Peter Deumelandt ${ }^{5}$, Peter Zimmermann ${ }^{6}$ and Wolfgang Wimmer ${ }^{7}$
}

\begin{abstract}
In 2009 the German funding programme for "Promoting Projects to Optimise the Use of Biomass for Energy Production" ("Biomass for Energy") has started and fostered a wide range of projects to combine sustainable energy supply and climatic protection. Certain projects are described to give an idea of the wide range of projects and the different aspects of sustainability which are addressed. Additionally a first product for the planned quality assurance of the results via a dedicated method handbook is given.
\end{abstract}

Keywords: biomass, bioenergy, residues, biomass gasification, regional bioenergy, climatic protection, sustainable energy supply, biomass incineration, biomass combustion, Absorption Enhanced Reforming Technology (AER), polygeneration, SNG (Renewable "Substitute Natural Gas"), Heatpipe-Reformer, co-generation, wood gasification plant, method handbook, greenhouse gas emission (GHG), supplying costs, life cycle assessment

\section{Introduction}

The challenges facing the world in regard to climatic protection can only be met by a sustainable energy supply. Biomass is the most important and versatile renewable energy source in Germany and, of course, in Europe (Figure 1).

The sustainable use of biomass has the potential to be of huge benefit in terms of climate and resource protection, security of energy supply and the development of rural areas.

The discussed disadvantages of the use of biomass for energy production such as food insecurity, greenhouse gas (GHG) emissions and biodiversity loss from land use, change or overuse of water and soil are taken into consideration in all new research projects. The biomass resources are limited, and must therefore be used effectively and in an energy-saving way.

\footnotetext{
* Correspondence: daniela.thraen@ufz.de

${ }^{1}$ Helmholtz-Zentrum für Umweltforschung GmbH - UFZ, DBFZ Deutsches BiomasseForschungsZentrum gemeinnützige $\mathrm{GmbH}$, Leipzig, Germany Full list of author information is available at the end of the article
}

For this reason, the German Federal Ministry for the Environment, Nature Conservation and Nuclear Safety (BMU) has drawn up a programme for "Promoting Projects to Optimise the Use of Biomass for Energy Production" ("Biomass for Energy") in the framework of the German Climate Initiative. The subject of the funding programme is the research and development of energy efficient technologies and the optimisation of processes and procedures in the field of power, heat and fuels from biomass. The results of these research processes are used for the development of a sustainable and manageable biomass strategy. Therefore the funding programme is supported by a service and support team, in which DT, DP and AG organise networking, method discussion and harmonisation, as well as quality assurance and dissemination of results.

\section{The projects}

Since the programme was launched in April 2009, several research projects, partially grouped in joint research projects, are focusing on the design and examination of improved biomass utilisation technologies. Projects for 


\section{Shares of renewable energy sources among total final energy consumption in Germany 2010}

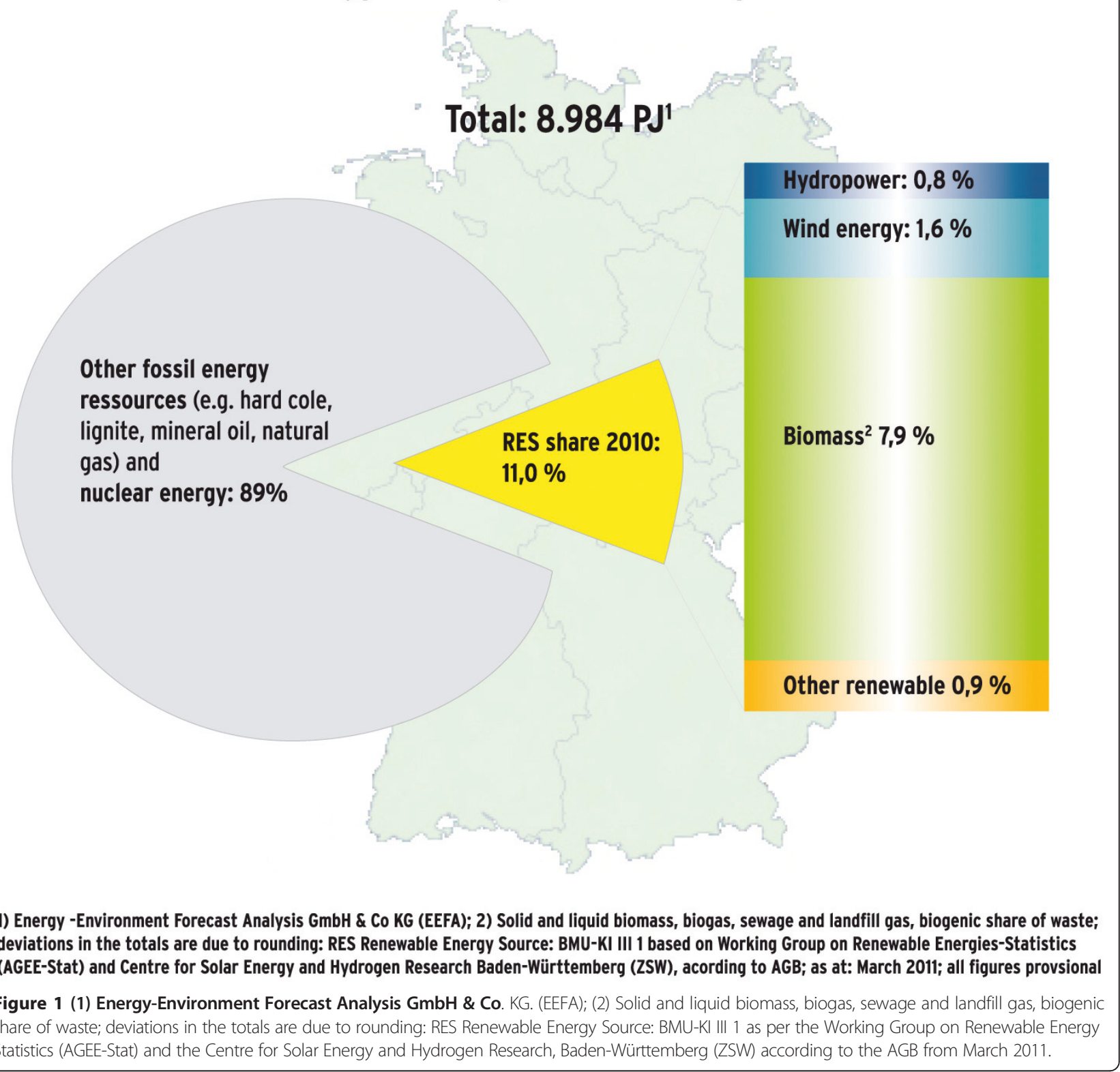

the use of residues, for the drawing up of regionally integrated and optimised local concepts (biomass incineration) as well as the development and presentation of biomass gasification technologies, have particular significance. Questions concerning knowledge, education and consultation and the social acceptability of biomass are also part of the programme. First of all, the practical work of the first 36 projects includes the creation of a reliable data base, optimisation approaches, concepts, biomass potential (by-products, waste, landscape management residues, agriculture and forestry) and feasibility studies. In addition, further 17 projects are funded in a second phase of the programme starting at the end of 2010. In this case, pilot and demonstration projects are at the centre of interest. The period of the funding programme is from 2009 to 2014 .

Chosen from the wide range of activities, three exemplary projects are presented:

1. Biomass-to-Gas: The Energetic Utilisation of Biomass Residues by Means of an Absorption Enhanced Reforming Technology (03KB011). 
2. Information on Sustainable Use of Agricultural Residues for the Provision of Bioenergy (03KB021).

3. The Optimisation of Regional Cycles for the Supply of Biogenic Fuels for Power Plants, quoting the example of the Biomassehof Achental (03KB053).

\section{R \& D Platform "BtG" Biomass-to-Gas: The} Energetic Utilisation of Biomass Residues by Means of an Absorption Enhanced Reforming Technology

(FuE-Plattform "BtG"-Energetische Nutzung biogener Reststoffe mit AER-Technologie) (03KB011)

The research activities in the field of polygeneration (integrated generation of three or more outputs such as heat, power and fuel are represented among others by the Research and Development Platform "Biomass-toGas: The Energetic Utilisation of Biomass Residues by Means of an Absorption Enhanced Reforming (AER) Technology" (03KB011).

The AER process which is investigated by the Centre for Solar Energy and Hydrogen Research of BadenWürttemberg produces a synthesis gas allowing for the polygeneration of power, heat, SNG (Renewable "Substitute Natural Gas") and Renewable Hydrogen [1]. The main advantage of the AER process is a high quality product, i.e. a gas with an increased $\mathrm{H}_{2}$ content and a reduced content of $\mathrm{CO}, \mathrm{CO}_{2}$, and tars [2]. In order to continually generate an $\mathrm{H}_{2}$-rich product gas, two fluidised-bed reactors are combined and a $\mathrm{CO}_{2}$-sorptive bed material (natural limestone) is circulated between them. The bed material transports heat into the allothermal gasification unit where it separates additional $\mathrm{CO}_{2}$ at temperatures less than $800^{\circ} \mathrm{C}$. Residual biomass char is burnt in the second reactor in order to heat and regenerate the bed material (releasing $\mathrm{CO}_{2}$ ) at temperatures higher than $800^{\circ} \mathrm{C}$. Due to the high $\mathrm{H}_{2}$ content and the adjusted composition of the product gas, the generation of SNG can be realised without $\mathrm{CO}_{2}$ separation in a single methanation step [3].

The R\&D topics, in which SS is involved, concentrate in particular on

- the characterisation and checking of the suitability of new biomass sources (e.g. residual biomass from landscape conservation) as alternatives for wood (in cooperation with Institute of Combustion and Power Plant Technology of Stuttgart University),

- the development of a hot gas cleaning concept for the generation of SNG (in cooperation with the DVGW research division of the Engler-Bunte-Institute of Karlsruhe University),

- the basic engineering of the generation of renewable hydrogen via pressure swing adsorption,

- the influence of pressure on $\mathrm{CO}_{2}$ absorption as well as on biomass conversion (Figure 2).

\section{Information on Sustainable Use of Agricultural Residues for the Provision of Bioenergy The Sustainable Use of Agricultural Residues for the Production of Bioenergy}

(Basisinformationen für eine nachhaltige Nutzung von landwirtschaftlichen Reststoffen zur Bioenergieerzeugung) (03KB021)

Within the project "Information regarding the Sustainable Use of Agricultural Residues for the Supply of Bioenergy" the potential of straw in Germany will be

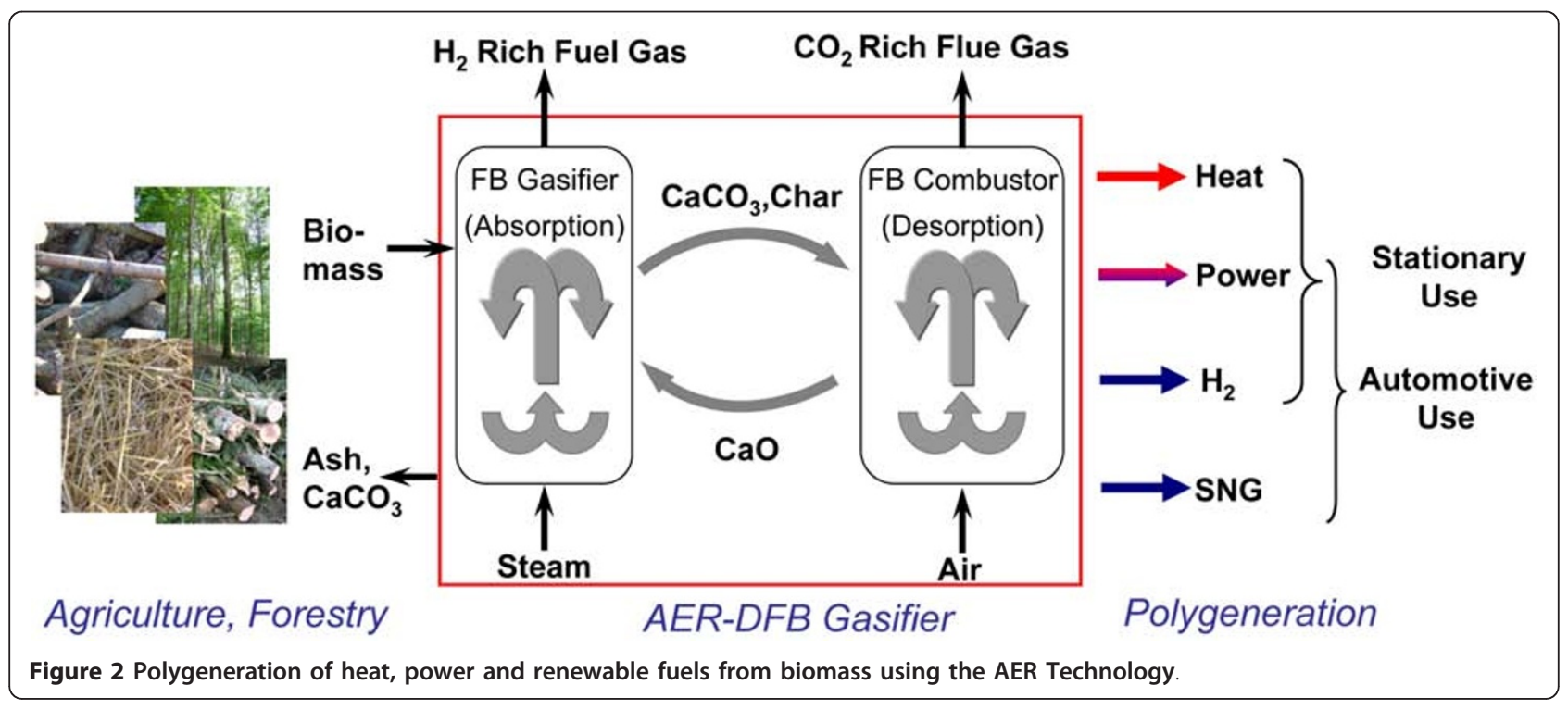


analysed under the consideration of ecological, technical and economic aspects. Work tasks are, among others, the determination of the potential by means of humus balancing, the analysis of climate impacts and the techno-economic analysis of the different straw providing pathways. PD and CW analyse for the first time, the potential of straw throughout Germany at a county level (NUTS3-level) by applying humus balancing, and according to the regional agricultural statistics of the years 1999, 2003 and 2007, the yields and the most relevant organic input and output flows as well as their impacts on the soil carbon pools are calculated [4-6]. The aim is to keep the soil organic matter balance stable and to remove only that amount of organic matter which does not disrupt this balance. The surplus straw also considers the proportion of the straw that can be removed through baling from a technical point of view and a potential material use rate of $10 \%$. To integrate the different sustainability aspects, $\mathrm{VZ}$ contributes to the analysis of the potential environmental impacts at an early stage to support the sustainable exploitation of mostly unused agricultural residues $[7,8]$ (Figure 3 ).

\section{The Optimisation of Regional Cycles for the Supply of Biogenic Fuels for Power Plants,} quoting the example of the Biomassehof Achental

(Optimierung regionaler Kreisläufe zur Bereitstellung biogener Brennstoffe für Energieerzeugungsanlagen am Beispiel Biomassehof Achental) (03KB053)

The bioenergy region of Achental, located in the south of Chiemgau, has set itself the target of covering its entire energy demand with energy produced from regional, regenerative sources by 2020. The different activities are coordinated by the Biomassehof Achental GmbH \& Co. KG. In collaboration with the Biomassehof Achental $\mathrm{GmbH} \& \mathrm{Co}$. KG, the agnion Operating GmbH \& Co. KG plans to build and operate a gasification plant, the so-called agnion Heatpipe-Reformer. With the HeatpipeReformer, electricity is generated, and the heat arising during co-generation (combined heat and power) is fed into the existing district heating network. This demonstration plant should speed up the market breakthrough for wood gasification plants. As more than half of the area of the Achental region is covered with forests, the fuel demand for the wood gasification plant can be covered by the regional potentials of forest energy wood,

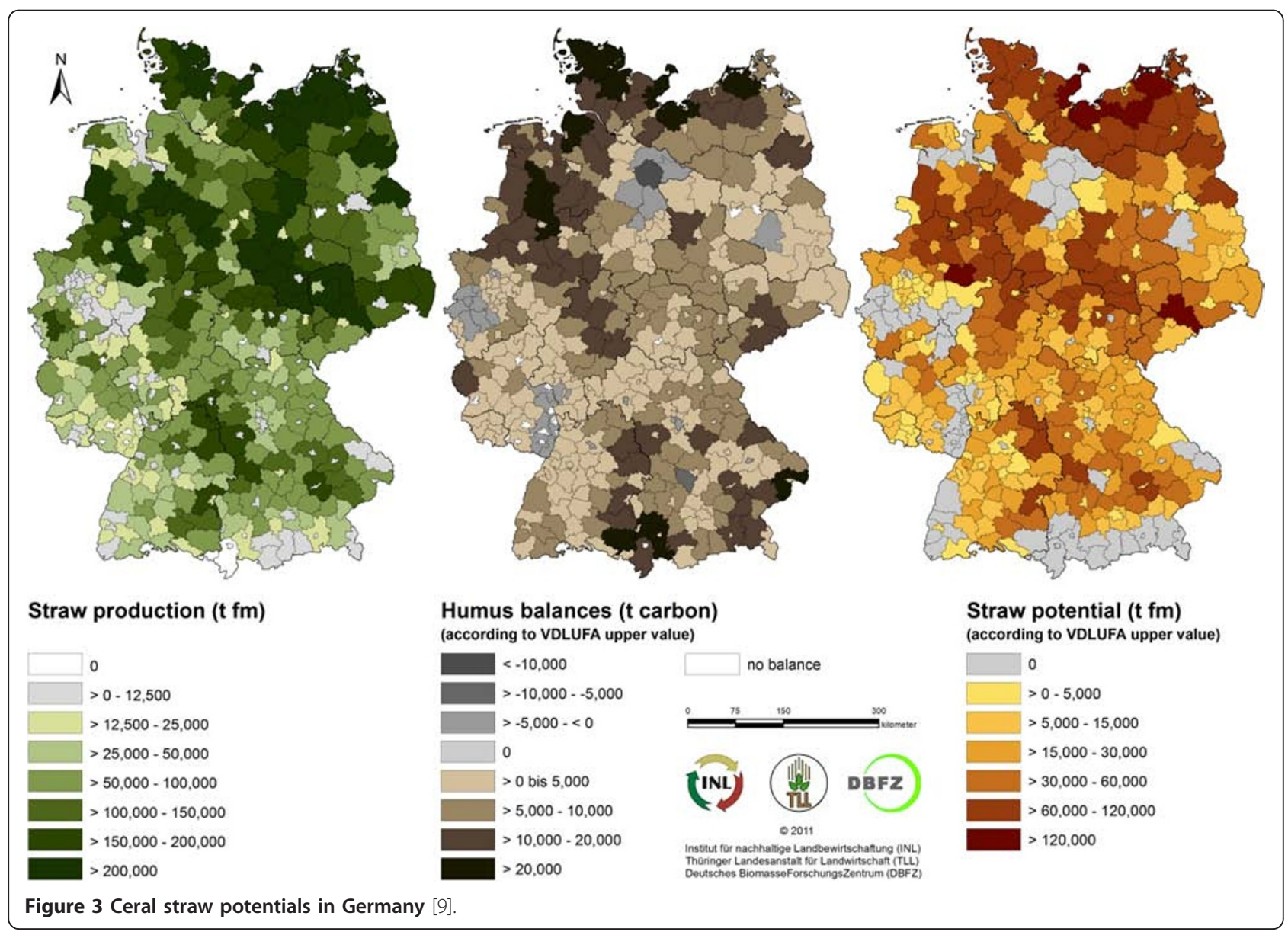


landscape maintenance wood and residual sawdust. Moreover, WW and PZ intend to optimise the technology in accordance with the different biomasses and to develop a regional cycle for the supply of biogenic fuels, in particular wood chips. The concept of Achental can, in principle, also be applied to comparable regions (Figure 4).

\section{Comparable methods}

For optimisation, benchmarks are needed in order to be able to measure it. This is especially true for research in regards to the use of biomass for energy production, as a variety of potential uses opens up many possible utilisation pathways. When they began their work in 2009, scientists from the "Biomass for Energy" funding programme were faced with the task of harmonising their combined methodological processes in order to make performance characteristics as well as cost calculations and accounting comparable. DT coordinated an intensive discussion process and the production of the "Methods Handbook - Part 1: Technological parameters, supplying costs, life cycle assessment" (Methodenhandbuch), which is intended for the use in the material flow-orientated assessment of research within the scope of the funding programme and the entire bioenergy sector.

In the past, a comparison of the data and results in the field of bioenergy research proved to be difficult, as no uniform standards and methods had been agreed upon by the scientific community. The need to harmonise the methods seemed therefore all the more urgent, since the individual projects in the "Biomass for Energy" funding programme were supposed to be evaluated according to the climate protection effects achieved. For example, these evaluations are undertaken on the basis of the biomass potential, the energy and material balance of conversion processes, economic efficiency calculations plus GHG reductions and other environmental effects.

In the "Methods Handbook", the GHG calculation of the entire process chain is carried out in accordance with the EU Renewable Energy Directive (EU RED 2009/28/EG), partially modified using Germany-specific comparators. The efficiency of test plants is comparedover a specific time frame-with plants that have already proven themselves and have been introduced into the market. In the case of new technological developments, a scenario-based view of the years 2020 to 2050 is also

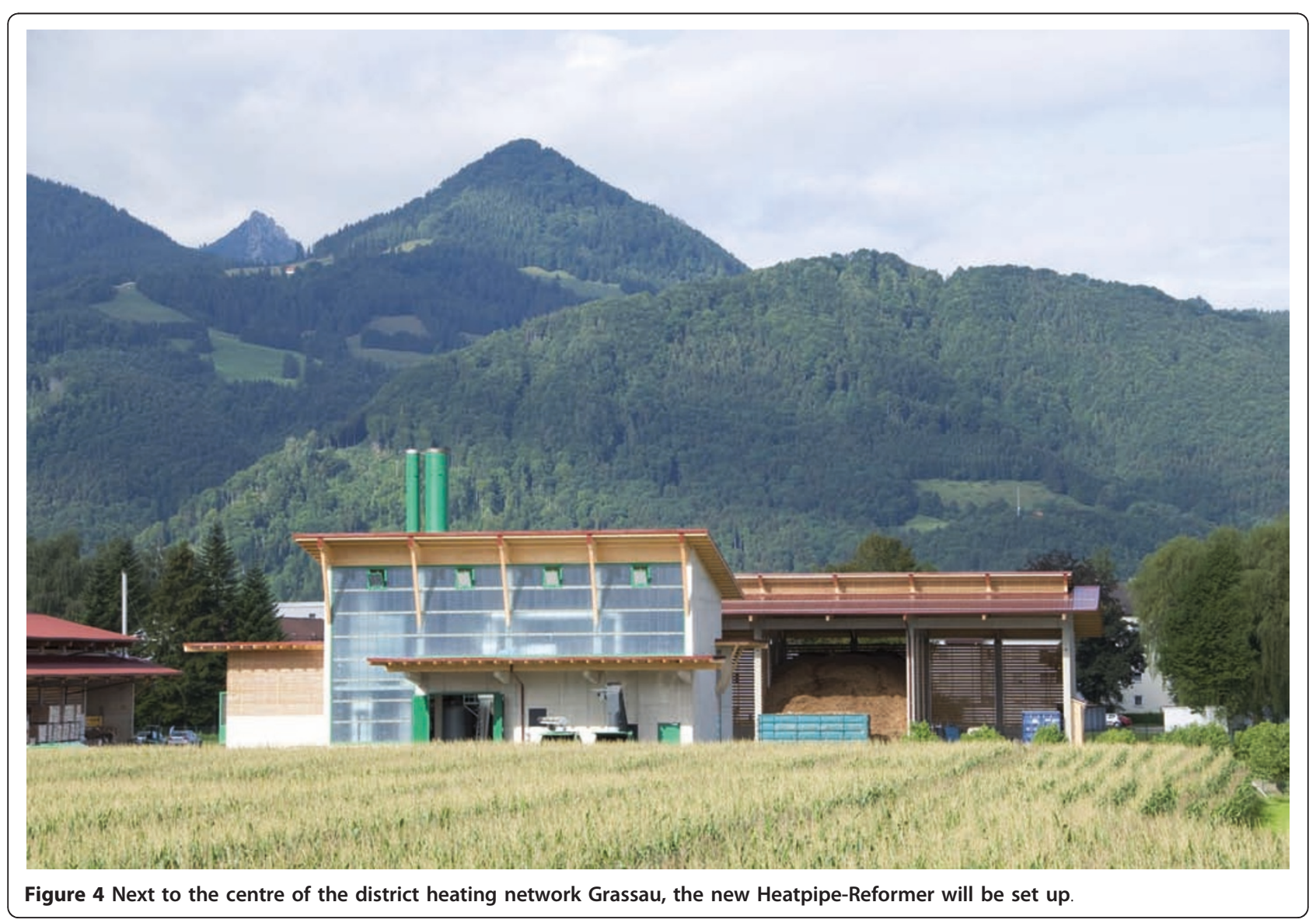


provided assuming that there will be a successful introduction of the system.

For instance, the raw material basis is assessed by means of a potential analysis or a description of the specific reference used. The energy contents of the biomass and the (bio-) energy sources are represented as calorific values in joules.

With the "Methods Handbook" the first step in developing an open standardisation process has been taken. For the first draft, 11 authors involved in the funding programme contributed their experience. The final version of the handbook is currently tested and will be published in 2012.

A German version of the "Methods Handbook-Part 1: Technological parameters, supplying costs, and life cycle assessment" is freely available for download: http://www. energetische-biomassenutzung.de/de/downloads/programminformationen.html.

\section{Information box}

Biomass = Material of biological origin excluding material embedded in geological formations and/or transformed to fossils. (1) Herbaceous biomass: Biomass from plants that have a non-woody stems which are dying at the end of the growing season. (2) Fruit biomass: Biomass from parts of a plant which hold seeds. (3) Woody biomass: Biomass from trees, bushes and shrubs [9].

\section{Author details \\ ${ }^{1}$ Helmholtz-Zentrum für Umweltforschung GmbH - UFZ, DBFZ Deutsches BiomasseForschungsZentrum gemeinnützige $\mathrm{GmbH}$, Leipzig, Germany ${ }^{2} \mathrm{DBFZ}$ Deutsches BiomasseForschungsZentrum gemeinnützige $\mathrm{GmbH}$, Leipzig, Germany ${ }^{3}$ Zentrum für Sonnenenergie und Wasserstoff-Forschung Baden- Württemberg (ZSW), Stuttgart, Germany ${ }^{4}$ Thüringer Landesanstalt für Landwirtschaft (TLL), Jena, Germany ${ }^{5}$ Institut für nachhaltige Landbewirtschaftung e.V. (INL), Saale, Germany ${ }^{6}$ agnion Operating GmbH \& Co.KG, Pfaffenhofen, Germany ${ }^{7}$ Biomassehof Achental GmbH \& Co. KG, Grassau, Germany}

\section{Competing interests}

The authors declare that they have no competing interests.

Received: 28 October 2011 Accepted: 9 December 2011

Published: 9 December 2011

\section{References}

1. Pfeifer $C_{1}$ Puchner $\mathrm{B}$, Hofbauer $\mathrm{H}$ (2007) In situ $\mathrm{CO}_{2}$ absorption in a dual fluidized bed biomass steam gasifier to produce a hydrogen rich syngas. Int J Chem Reactor Eng 5:A9

2. Koppatz S, Pfeifer C, Rauch R, Hofbauer H, Marquard-Moellenstedt $T$, Specht $M(2009) \mathrm{H}_{2}$ rich product gas by steam gasification of biomass with in situ $\mathrm{CO}_{2}$ absorption in a dual fluidized bed system of $8 \mathrm{MW}$ fuel input. Fuel Process Technol 90:914-921. doi:10.1016/j.fuproc.2009.03.016.

3. Brellochs J, Marquard-Moellenstedt T, Zuberbuehler U, Specht M, Koppatz S, Pfeifer C, Hofbauer H (2009) Stoichiometry adjustment of biomass steam gasification in DFB process by in situ $\mathrm{CO}_{2}$ absorption. Proceedings of the First International Conference on Polygeneration Strategies. Vienna

4. Leithold G, Hülsbergen KJ, Michel D, Schönmeier H (1997)

Humusbilanzierung-Methoden und Anwendung als Agrar-Umweltindikator. Umweltverträgliche Pflanzenproduktion-Indikatoren, Bilanzierungsansätze und ihre Einbindung in Ökobilanzen. Zeller Verlag, Deutsche Bundesstiftung Umwelt. Osnabrück pp 43-55

5. Hülsbergen KJ (2003) Entwicklung und Anwendung eines

Bilanzierungsmodells zur Bewertung der Nachhaltigkeit landwirtschaftlicher Systeme. Shaker Verlag, Aachen

6. Weiser C, Vetter A, Reinicke F, Wagner B (2011) Ehrlich währt am längstenBestimmung des deutschlandweiten Getreidestrohpotenzials auf

Landkreisebene unter Anwendung verschiedener Humusbilanzmethoden. Bauernzeitung 19(Woche):26-28

7. Weiser $C$, Zeller $V$, Thrän $D$, Vetter $A$ (2011) Distribution of sustainable straw potentials in Germany. Proceedings of the 19th European Biomass Conference and Exhibition-From Research to Market Deployment. ETA Florence

8. Zeller V, Weiser C, Hennenberg K, Reinicke F, Schaubach K, Thrän D, Vetter A, Wagner B (2011) Basisinformationen für eine nachhaltige Nutzung landwirtschaftlicher Reststoffe zur Bioenergiebereitstellung. Schriftenreihe des BMU-Förderprogramms "Energetische Biomassenutzung" - Band 2. DBFZ Leipzig

9. Solid biofuels-terminology, definitions and descriptions. Final draft of the norm 14588. European Committee for Standardisation (CEN), Brussels

doi:10.1186/2192-0567-1-7

Cite this article as: Thrän et al:: Optimisation of the use of biomass for energy production (Optimierung der energetischen Biomassenutzung)-a funding programme introduces itself. Energy, Sustainability and Society $20111: 7$

\section{Submit your manuscript to a SpringerOpen ${ }^{\mathcal{D}}$ journal and benefit from:}

- Convenient online submission

- Rigorous peer review

- Immediate publication on acceptance

- Open access: articles freely available online

- High visibility within the field

- Retaining the copyright to your article

Submit your next manuscript at $>$ springeropen.com 